Article

\title{
Nigella and Milk Thistle Seed Oils: Potential Cytoprotective Effects against $7 \beta$-Hydroxycholesterol-Induced Toxicity on SH-SY5Y Cells
}

\author{
Souha Hammouda ${ }^{1}$, Imen Ghzaiel ${ }^{1}$, Pol Picón-Pagès ${ }^{2} \mathbb{D}$, Wiem Meddeb ${ }^{3}$, Wided Khamlaoui ${ }^{1}$, Sonia Hammami ${ }^{1}$, \\ Francisco J. Muñoz ${ }^{2}$ (D), Mohamed Hammami ${ }^{1}$ and Amira Zarrouk ${ }^{1,4, *}$
}

check for updates

Citation: Hammouda, S.; Ghzaiel, I.; Picón-Pagès, P.; Meddeb, W.; Khamlaoui, W.; Hammami, S.; Muñoz, F.J.; Hammami, M.; Zarrouk, A. Nigella and Milk Thistle Seed Oils: Potential Cytoprotective Effects against $7 \beta$-HydroxycholesterolInduced Toxicity on SH-SY5Y Cells. Biomolecules 2021, 11, 797. https:// doi.org/10.3390/biom11060797

Academic Editor: Fabio Di Domenico

Received: 19 April 2021

Accepted: 24 May 2021

Published: 27 May 2021

Publisher's Note: MDPI stays neutral with regard to jurisdictional claims in published maps and institutional affiliations.

Copyright: (c) 2021 by the authors. Licensee MDPI, Basel, Switzerland. This article is an open access article distributed under the terms and conditions of the Creative Commons Attribution (CC BY) license (https:/ / creativecommons.org/licenses/by/ $4.0 /)$.
1 Biochemistry Laboratory, LR12ES05 Nutrition-Functional Foods and Vascular Health, Faculty of Medicine, University of Monastir, Monastir 5019, Tunisia; souhahammouda51@gmail.com (S.H.); imenghzaie193@gmail.com (I.G.); wided.92.92@gmail.com (W.K.); sonia.hammami@fmm.rnu.tn (S.H.); mohamed.hammami@fmm.rnu.tn (M.H.)

2 Laboratory of Molecular Physiology, Faculty of Health and Life Sciences, Universitat Pompeu Fabra, 08003 Barcelona, Spain; pol.picon@upf.edu (P.P.-P.); paco.munoz@upf.edu (F.J.M.)

3 Faculty of Sciences, University of Carthage, Bizerte 7021, Tunisia; wiem.meddeb@gmail.com

4 Faculty of Medicine, Sousse, University of Sousse, Sousse 4000, Tunisia

* Correspondence: zarroukamira@gmail.com; Tel.: +216-94-837-999

\begin{abstract}
Oxysterols are assumed to be the driving force behind numerous neurodegenerative diseases. In this work, we aimed to study the ability of $7 \beta$-hydroxycholesterol $(7 \beta-\mathrm{OHC})$ to trigger oxidative stress and cell death in human neuroblastoma cells (SH-SY5Y) then the capacity of Nigella sativa and Milk thistle seed oils (NSO and MTSO, respectively) to oppose $7 \beta$-OHC-induced side effects. The impact of $7 \beta-\mathrm{OHC}$, associated or not with NSO or MTSO, was studied on different criteria: cell viability; redox status, and apoptosis. Oxidative stress was assessed through the intracellular reactive oxygen species (ROS) production, levels of enzymatic and non-enzymatic antioxidants, lipid, and protein oxidation products. Our results indicate that $7 \beta-\mathrm{OHC}(40 \mu \mathrm{g} / \mathrm{mL})$ exhibit $\mathrm{pr}-$ oxidative and pro-apoptotic activities shown by a decrease of the antioxidant enzymatic activities and an increase of ROS production, lipid, and protein oxidation end products as well as nitrotyrosine formation and caspase 3 activation. However, under the pre-treatment with NSO, and especially with MTSO $(100 \mu \mathrm{g} / \mathrm{mL})$, a marked attenuation of oxidative damages was observed. Our study suggests harmful effects of $7 \beta-\mathrm{OHC}$ consisting of pro-oxidative, anti-proliferative, and pro-apoptotic activities that may contribute to neurodegeneration. NSO and especially MTSO showed potential
\end{abstract} cytoprotection against the cytotoxicity of $7 \beta-\mathrm{OHC}$.

Keywords: $7 \beta$-hydroxycholesterol; neuroblastoma cells; cellular oxidative stress; neurodegenertion; antioxidants enzymes; antioxidants

\section{Introduction}

The involvement of lipid metabolism disorders in neurodegenerative diseases is widely reported [1-4].

Cholesterol oxides, also named oxysterols, are 27-carbon intermediates or end-product of cholesterol metabolism. These molecules can be brought by the diet, formed by autooxidation and/or enzymatic processes. Some oxysterols, such as 7-ketocholesterol (7KC) and $7 \beta$-hydroxycholesterol $(7 \beta-\mathrm{OHC})$, exhibit cytotoxic and pro-inflammatory activities, which are characteristics of several chronic diseases and age-related diseases $[2,5,6]$. Unlike cholesterol, oxysterols are also able to cross the blood-brain barrier. Thus, a growing interest in elucidating their implication in the development of neurodegenerative diseases has emerged.

As the brain is rich in cholesterol [7], this makes it vulnerable to reactive oxygen species (ROS) attack with subsequently oxysterols' formation, such as $7 \beta-\mathrm{OHC}$. In Parkinson's 
disease (PD), an accumulation of $7 \beta-\mathrm{OHC}$ was observed in the visual cortex [8]. Likewise, high levels of $7 \beta-\mathrm{OHC}$ were detected in the putamen in Huntington's disease (HD) [9]. In Alzheimer's disease (AD) condition, an association of high levels of $7 \beta-\mathrm{OHC}$ with oxidative stress biomarkers was reported in plasma of $\mathrm{AD}$ patients [4]. It is noteworthy that $\mathrm{AD}$ is characterized by the accumulation of amyloid-beta $(A \beta)$, produced from the amyloid precursor protein (APP) via a proteolysis reaction. Nelson and Alkon reported that both $A \beta$ and APP contribute to the enhancement of the neurotoxic effects of $7 \beta-\mathrm{OHC}$ [10]. In vitro, $7 \beta-\mathrm{OHC}$ was found to promote oxiapoptophagy in different cell lines, which is a mixedmode of cell death associated with oxidative stress, apoptosis, and autophagy. Furthermore, this molecule induced modifications of lipid profile as well as mitochondria, lysosome, and peroxisome dysfunctions [11]. $7 \beta-\mathrm{OHC}$ was also associated with $\mathrm{A} \beta$ generation and neuron death [10]. In cultured rat hippocampal neuronal cells, the APP induced the oxidation of cholesterol to $7 \beta-\mathrm{OHC}$ [10]. All this evidence supports the contribution of oxysterols, in particular $7 \beta-\mathrm{OHC}$, in neurodegenerative diseases through oxidative stress. Thus, identifying natural products preventing or attenuating the oxysterol-induced deleterious effects could be of interest.

Antioxidant therapy is believed to be an essential tool in the prevention and treatment of several oxidative stress-related diseases $[12,13]$. In traditional medicine, vegetable oils constitute an important source of bioactive molecules such as tocopherols and polyphenols, which exhibit potent neuroprotective properties and can cross the blood-brain barrier [14-16]. In the present study, our interest has been given to milk thistle (Silybum marianum) and nigella (Nigella sativa), plants known to have antioxidant properties.

In the literature, several researchers pointed out to Nigella seeds oil (NSO) antiinflammatory and antioxidant activities [17-19]. The biological activity of this oil was associated not only to scavenge free radicals but also to modulate the endogenous antioxidant systems. Among the compounds in NSO, thymoquinone is known as a potent antioxidant [20,21]. Milk thistle seeds oil (MTSO) is also widely known in phytotherapy especially in the treatment of liver diseases. This oil contains several bioactive components including antioxidants, tocopherols, and carotenoids which may explain its therapeutic effect [22]. In vitro, milk thistle was found to promote differentiation and neuronal survival [23]. Besides, it protects rat hippocampus neurons against cell death [23].

In this line and based on the literature, we aimed to study the capacity of $7 \beta-\mathrm{OHC}$ to trigger cellular modifications involved in the neurodegenerative diseases such as oxidative stress and cell death on human neuroblastoma cell line (SH-SY5Y cells) then to evaluate the antioxidant properties of NSO and MTSO and their cytoprotective capacity against $7 \beta$-OHC-induced side effects.

Overall, our results indicate that $7 \beta-\mathrm{OHC}$ induce deleterious effects on SH-SY5Y cells consisting of ROS overproduction, lipid and protein oxidation, loss of antioxidant enzyme activities, and induction of apoptosis. NSO and MTSO attenuated 7 $\beta$-OHC-induced side effects. A more significant effect was observed with MTSO, though. These findings consolidate the harmful effects of $7 \beta-\mathrm{OHC}$ consisting of pro-oxidative and pro-apoptotic activities which may contribute to neurodegeneration. NSO and especially MTSO showed potential cytoprotection against the cytotoxicity of $7 \beta-\mathrm{OHC}$.

\section{Materials and Methods}

2.1. Chemical Contents and Antioxidants Activities of NSO and MTSO

\subsubsection{Seed Oils Preparation}

The seeds oils were extracted via cold-pressing by Dr. Wiem Meddeb (Higher institute of Biotechnology, Beja, Tunisia) and stored at $\left(-20^{\circ} \mathrm{C}\right)$ for analysis as previously reported [19].

\subsubsection{Determination of Lipid Contents}

Lipids were extracted from seed oils as described by Moilanen and Nikkari [24]. C19:0 was added as an internal standard. After transmethylation of lipids with boron 
trifluoride in methanol, methyl esters were extracted with hexane and then analyzed by gas chromatography using a Hewlett Packard Gas Chromatograph (Hewlett Packard 5890, Palo Alto, CA, USA) with HP-Innovax column $(30 \mathrm{~m} \times 0.25 \mathrm{~mm} 0.25 \mu \mathrm{m}$ film thickness: Hewlett-Packard, Palo Alto, CA, USA). The identification of the fatty acid methyl esters was carried out following a comparison with synthetic standards (Sigma-Aldrich, France). The results were analyzed with the EZ Chrom Elite software (Agilent Technologies, Massy, France) and data were shown as $\%$ of total fatty acids.

\subsubsection{Determination of Tocopherol and Polyphenol Contents}

Tocopherol analysis was performed as previously described [25]. Briefly, oil samples were resuspended in high-performance liquid chromatography (HPLC) mobile phase comprising acetonitrile/methanol, ammonium acetate/water/dichloromethane (50 mM) (700:150:50:100, $v / v / v / v)$, then vortexed for $30 \mathrm{~s}$. For the analysis, $80 \mu \mathrm{L}$ of each sample were injected into a reverse phase HPLC system.

Polyphenol analysis was performed as described previously [25]. Oil samples were dissolved in $6 \mathrm{~mL}$ of petroleum ether. The mixture was cleansed by a solid-phase extraction (SPE) cartridge silica, previously conditioned in petroleum ether; then the cartridge was rinsed with $12 \mathrm{~mL}$ of petroleum ether and underwent a flux of nitrogen for $10 \mathrm{~min}$. Polyphenolic compounds were eluted with a mixture of methanol/distilled water $(80 / 20$; $v / v$ ) and subsequently with $8 \mathrm{~mL}$ of acetonitrile. After evaporation of the eluate at $50{ }^{\circ} \mathrm{C}$ using low pressure, the residue was dissolved with a mixture of methanol/distilled water $(60 / 40 ; v / v)$ and filtered using a $0.45 \mathrm{pm}$ nylon membrane. Polyphenol analysis was carried out at Lara-Spiral laboratory, using HPLC-mass spectrometry (HPLC-MS).

\subsubsection{DPPH Free Radical Scavenging Activity}

The 2, 2-diphenyl-1-picrylhydrazyl $\left(\mathrm{C}_{18} \mathrm{H}_{12} \mathrm{~N}_{5} \mathrm{O}_{6}\right.$; DPPH) assay was used to measure the free radical scavenging activity of seed oils. DPPH was solubilized in methanol and added to each oil sample. All samples were incubated in darkness for $30 \mathrm{~min}$ and the absorbance was read at $517 \mathrm{~nm}$. The ascorbic acid (AA) and water were used as positive and negative controls, respectively. The DPPH free radical scavenging activity was calculated as follows:

DPPH free radical scavenging activity $(\%)=(($ Absorbance negative control - Absorbance sample $) /$

$$
\text { Absorbance negative control) } \times 100
$$

\subsubsection{Ferric Reducing-Antioxidant Power (FRAP)}

The FRAP test, which consists of reducing ferric iron $\left(\mathrm{Fe}^{3+}\right)$ to ferrous iron $\left(\mathrm{Fe}^{2+}\right)$, is used to determine the antioxidant potential of some compounds. The test was performed as described by Lim et al. [26]. Briefly, $0.4 \mathrm{~mL}$ of oils samples (prepared at different dilutions) were added to $1 \mathrm{~mL}$ of $0.2 \mathrm{M}$ phosphate buffer ( $\mathrm{pH}$ 6.6) and $1 \mathrm{~mL}$ potassium ferricyanide (1\%) complex. The mixtures were incubated in darkness at $50^{\circ} \mathrm{C}$ for $30 \mathrm{~min}$. Then, $1 \mathrm{~mL}$ of trichloroacetic acid (TCA) solution $(10 \%)$ was added to stop the reaction. After centrifugation at $3000 \mathrm{~g}$ for $10 \mathrm{~min}, 1 \mathrm{~mL}$ of supernatant of each sample was mixed with $0.2 \mathrm{~mL}$ of $1 \%$ freshly prepared $\mathrm{FeCl}_{3}$ solution. The absorbance was measured at $700 \mathrm{~nm}$. AA was used as a positive control. The FRAP of the oils was calculated as follows:

FRAP $(\%)=(($ Absorbance sample $/$ Absorbance blank $) \times 100) /$ Absorbance sample

\subsubsection{Chelation Power on Ferrous $\left(\mathrm{Fe}^{2+}\right)$ Ions}

The chelating effect of the seed oils on ferrous ions was determined according to the method of Dinis et al. [27] with some modifications. Briefly, different concentrations of each oil were prepared at $1 \mathrm{~mL}$ and each sample was raised to $4.7 \mathrm{~mL}$ with distilled water. $100 \mu \mathrm{L}$ of $2 \mathrm{mM} \mathrm{FeCl}_{2}$ solution was added and the samples were mixed. Then, $200 \mu \mathrm{L}$ of $5 \mathrm{mM}$ ferrozine was added to the mixture. After agitation, the samples were incubated at room 
temperature (RT) for $10 \mathrm{~min}$ and the absorbance was read at $562 \mathrm{~nm}$. The iron-chelating power was determined as follows:

Iron-chelating power $(\%)=(($ Absorbance negative control - Absorbance sample $) /$

Absorbance negative control) $\times 100$

\subsection{In Vitro Study}

\subsubsection{Cell Culture}

Human neuroblastoma cells (SH-SY5Y) were cultured in Ham's F12 GlutaMax medium (F12 medium; Gibco, Zaragoza, Spain) supplemented with 15\% $(v / v)$ heat-inactivated fetal bovine serum (FBS; Gibco, Zaragoza, Spain) and 1\% antibiotics (penicillin, streptomycin) (Gibco, Zaragoza, Spain) in a humidified atmosphere containing $5 \% \mathrm{CO}_{2}$.

\subsubsection{Cell Treatments}

$7 \beta-\mathrm{OHC}$ was provided by Mohammad Samadi (University of Lorraine, Metz, France). A stock solution of $7 \beta-\mathrm{OHC}(800 \mu \mathrm{g} / \mathrm{mL}=2 \mathrm{mM})$ was prepared as described by Ragot et al. [28]. Cells were seeded in 96, 24, or six-well plates. After $24 \mathrm{~h}$, the growth medium was removed and cells were cultured in the absence or in the presence of $7 \beta-\mathrm{OHC}$ at various concentrations $(10,20,30,40,50$, and $60 \mu \mathrm{g} / \mathrm{mL})$ for $24 \mathrm{~h}$. Hydrogen peroxide $\left(\mathrm{H}_{2} \mathrm{O}_{2}\right.$, Sigma, Madrid, Spain) was used as a positive control of cytotoxicity. All experiments were performed using subtoxic conditions of $7 \beta-\mathrm{OHC}$ (able to induce mild oxidative stress and cell death).

Stock solutions of NSO and MTSO were prepared at 10\% $(v / v)$ in dimethyl sulfoxide (DMSO). After $24 \mathrm{~h}$ of culture, cells were incubated with $7 \beta-\mathrm{OHC}$ for $24 \mathrm{~h}$ with or without NSO or MTSO. Oils were added to the cells $2 \mathrm{~h}$ before the challenge with $7 \beta-\mathrm{OHC}$. Trolox (synthetic polar analog of vitamin E, (Sigma, Madrid, Spain), was used as a positive control for cytoprotection. Treatment with $7 \beta-\mathrm{OHC}$ or $\mathrm{H}_{2} \mathrm{O}_{2}$ was maintained for $24 \mathrm{~h}$ except in the experiment of ROS measurement in which cells were treated for only $15 \mathrm{~min}$ to assess instantaneous ROS production.

\subsubsection{Cell Viability by MTT Assay}

Methyl thiazolyl-diphenyl-Tetrazolium Bromide (MTT) assay evaluates cell survival due to its conversion into blue formazan by the succinate dehydrogenase [29]. SH-SY5Y cells were seeded at $25 \times 10^{3}$ cells/well in a 96-well plate with $100 \mu \mathrm{L}$ of culture medium and treated as described in the Section 2.2.2. $2 \mathrm{~h}$ before the end of the treatment, $10 \%$ (regarding cell medium volume) of MTT stock solution $(5 \mathrm{mg} / \mathrm{mL}$ ) was added to the cells. The medium was removed, and formazan was solubilized by adding $100 \mu \mathrm{L}$ of DMSO (Sigma-Aldrich, Madrid, Spain), and the absorbance of each well was read at $540 \mathrm{~nm}$ and $650 \mathrm{~nm}$ (as reference) using an absorbance plate reader (BMG Labtech Fluostar Optima. Ortenberg, Germany). Data are expressed as the percentage of MTT reduction relative to the absorbance of untreated cells (controls).

\subsubsection{Cell Counting by Trypan Blue Exclusion Test}

At the end of treatments, adherent and non-adherent cells were collected by trypsinization. Cells were counted with a hemocytometer under a light microscope in the presence of trypan blue $(v / v)$ (Thermo Fisher Scientific, Barcelona, Spain), which stains non-viable cells in blue. Data are expressed as the total viable cells $\left(\times 10^{3}\right) /$ well.

\subsubsection{Intracellular ROS Measurement by $\mathrm{H}_{2}$ DCFDA Fluorescence Assay}

The capacity of $7 \beta-O H C$ to induce ROS production in SH-SY5Y cells was evaluated using $2^{\prime} 7^{\prime}$-dichlorofluorescein diacetate $\left(\mathrm{H}_{2} \mathrm{DCFDA}\right)$ fluorescence assay. This compound enters cells and is transformed into $2^{\prime} 7^{\prime}$-dichlorofluorescein (DCF) by the cell esterases and emit fluorescence when oxidized by ROS. SH-SY5Y cells were seeded at a density of $30 \times 10^{4}$ cells $/ \mathrm{mL}$ in a 24 -well plate and then incubated for $24 \mathrm{~h}$ at $37^{\circ} \mathrm{C}$. Following incubation, the medium was removed; the cells were washed twice with Phosphate-Buffered 
Saline (PBS; pH 7.2) and incubated with a medium containing $10 \mu \mathrm{M}$ of $\mathrm{H}_{2}$ DCFDA for $30 \mathrm{~min}$. After incubation, the culture supernatant was removed, and cells were incubated for $15 \mathrm{~min}$ with $7 \beta-\mathrm{OHC}(40 \mu \mathrm{g} / \mathrm{mL}$ ) in PBS ( $\mathrm{pH} 7.2) . \mathrm{H}_{2} \mathrm{O}_{2}$ was used as a positive control. Fluorescence was read at $485 \pm 10 \mathrm{~nm}$ for excitation and $530 \pm 12.5 \mathrm{~nm}$ for emission [30] using a fluorescence microplate reader (BioTek Synergy HTX, Winooski, VT, USA).

\subsubsection{Determination of the Enzymatic and Non-Enzymatic Antioxidants Levels}

Total superoxide dismutase (SOD) activity was assessed in cells according to Beauchamp and Fridovich method [31]. The assay measures the ability of SOD to inhibit the nitroblue tetrazolium chloride (NBT) reduction. Briefly, cell lysate was added to the reaction mixture (50 mM in potassium phosphate buffer, pH 7.8), $0.1 \mathrm{mM}$ EDTA, $13 \mathrm{mM}$ L-methionine, $2 \mu \mathrm{M}$ riboflavin, and $75 \mathrm{mM}$ nitroblue tetrazolium (NBT). The developed blue color (formazan) in the reaction is proportional to SOD activity and was measured at $560 \mathrm{~nm}$. Units of SOD activity are expressed as the amount of enzyme required to inhibit the reduction of NBT by $50 \%$, and the activity is expressed as a percentage of controls.

Glutathione peroxidase (GPx) activity was measured as described by Flohe and Günzler [32]. The assay is based on glutathione (GSH) oxidation by GPx in the presence of 5-5'-Dithio-bis (2-nitrobenzoic acid) (DTNB). Cell lysates were incubated with $0.1 \mathrm{mM}$ of GSH and PBS (50 mM, pH 7.8) for $5 \mathrm{~min}$. The reaction was initiated by adding $\mathrm{H}_{2} \mathrm{O}_{2}$ $(1.3 \mathrm{mM})$ and stopped by adding TCA $(1 \%)$. After incubation at $4{ }^{\circ} \mathrm{C}$ for $30 \mathrm{~min}$, the mixture was centrifuged at $1000 \times g$ for $10 \mathrm{~min}$ and the supernatant was transferred into new tube. DTNB was then added, and the absorbance was read at $412 \mathrm{~nm}$. GPx activity is expressed as percentage of control cells.

Thiol (SH) groups play a potent role in the protection against free radicals. SH group levels were measured as described by Faure and Lafon [33]. Cell lysates were mixed with phosphate buffer $(50 \mathrm{mM}, \mathrm{PH}=8)$ and DTNB and incubated in the dark at RT for $15 \mathrm{~min}$. The absorbance of the resulting product was read at $415 \mathrm{~nm}$ and data are expressed as $\mu \mathrm{mol} / \mathrm{mg}$ of protein.

\subsubsection{Determination of Lipid Peroxidation Product Levels}

Lipid peroxidation was assessed indirectly in SHSY5Y cells by measuring the production of malondialdehyde (MDA) and conjugated dienes (CD). The cell lysates were obtained by sonication followed by centrifugation at $20,000 \times g$ for $30 \mathrm{~min}$. Protein content in cell lysate was determined by the Bradford method [34] using bovine serum albumin (BSA) as a standard.

The level of MDA was determined as described by Yoshioka et al. [35]. To precipitate the proteins, cell lysate was mixed with trichloroacetic acid (20\%). Thiobarbituric acid $(0.67 \%)$ was added later, and the mixture was incubated for $30 \mathrm{~min}$ at $95^{\circ} \mathrm{C}$. After cooling the mixture at RT, $4 \mathrm{~mL}$ of n-butanol was added, and the absorbance was measured at $530 \mathrm{~nm}$ using a spectrophotometer. MDA level was calculated using the molar extinction coefficient $\left(1.56 \cdot 10^{-3} \mathrm{mM}^{-1} \cdot \mathrm{cm}^{-1}\right)$. Data are expressed in nmoles $/ \mathrm{mg}$ of protein.

The CD level was determined as described by Esterbauer et al. [36]. The method is based on extracting lipids using a chloroform-methanol (2v:1v) mixture. The extracted lipids were redissolved in hexane for analysis, and CD concentration was determined using the molar extinction coefficient $\left(2.52 \times 104 \mathrm{M}^{-1} \cdot \mathrm{cm}^{-1}\right)$. Data are expressed as $\mu \mathrm{moles}$ of hydroperoxide/mg of protein.

\subsubsection{Determination of Protein Oxidation Products}

Alongside lipids, proteins can also be damaged by ROS. The determination of carbonylated proteins (CP) level was determined spectrophotometrically as described previously [37]. Data are expressed as $\mu$ moles/mg of protein. 


\subsubsection{Nitrotyrosination Study by Immunocytochemistry}

SH-SY5Y cells were seeded on coverslips at $30 \times 10^{4}$ cells/well in 24-wells plates. After treatment, cells were fixed with $4 \%$ paraformaldehyde (PFA) for $10 \mathrm{~min}$. Cells were then permeabilized with $0.1 \%$ Triton X-100 (Sigma-Aldrich, Madrid, Spain) in 1X PBS for $10 \mathrm{~min}$ and blocked using a blocking buffer (2\% BSA (Sigma-Aldrich, Madrid, Spain) in $1 \mathrm{X}$ PBS for $1 \mathrm{~h}$ at RT. Firstly, coverslips were incubated overnight at $4{ }^{\circ} \mathrm{C}$ with the primary antibody; anti-nitrotyrosine (1:200, Thermo Fisher Scientific, Barcelona, Spain) diluted in blocking buffer, then incubated in darkness with Alexa rabbit 488 conjugated secondary antibody (1:2000; Thermo Fisher Scientific, Barcelona, Spain), diluted in blocking buffer for $1 \mathrm{~h}$ at RT. Cells were then stained with 4',6-diamidino-2-phenylindole (DAPI) (1:1000; Thermo Fisher Scientific, Barcelona, Spain) for $15 \mathrm{~min}$. Finally, coverslips were mounted on glass slides in $8 \mu \mathrm{l}$ of Fluoromount (Southern Biotech, Birmingham, AL, USA).

\subsubsection{Caspase 3 Activation Study}

SH-SY5Y cells were seeded on coverslips at $30 \times 10^{4}$ cells/well in 24- well plates. After treatment, cells were fixed with PFA (4\%) and permeabilized with $0.1 \%$ Triton X-100 in PBS at RT. Cells were blocked in 2\% BSA at RT for $1 \mathrm{~h}$ then incubated overnight at $4{ }^{\circ} \mathrm{C}$ with 1:100 rabbit anti-cleaved Caspase-3 antibody (Cell Signaling). Cells were washed with PBS $(3 \times 5 \mathrm{~min})$ and incubated with Alexa rabbit 488 conjugated secondary antibody (1:2000; Thermo Fisher Scientific, Barcelona, Spain) for $1 \mathrm{~h}$ at RT. Cells were rinsed $(3 \times 5 \mathrm{~min})$ and stained with DAPI (1:1000; Thermo Fisher Scientific, Barcelona, Spain). Coverslips were mounted with Fluoromount (Southern Biotech, Birmingham, AL, USA). Digital images were taken with a Leica TCS SP confocal microscope with the Leica confocal software. Analysis and quantification were performed using Image J software.

\subsection{Statistical Analysis}

Statistical analysis was performed using SPSS version 22 (Statistical Package for Social Science, SPSS Inc., Chicago, IL, USA). Data were represented as mean \pm standard deviation (SD). Analyses were carried out with T-test student and/or the Mann-Whitney U-test. Data were considered statistically different at a value of $p \leq 0.05$.

\section{Results}

3.1. Biochemical Composition and Antioxidants Activities of NSO and MTSO

\subsubsection{NSO and MTSO Contents Analysis}

The biochemical composition of NSO and MTSO (fatty acids, tocopherols, and polyphenols) is shown in Table 1.

Table 1. Fatty acids, tocopherols, and polyphenols contents in NSO and MTSO.

\begin{tabular}{ccc}
\hline & NSO & MTSO \\
\hline \multicolumn{2}{c}{ Fatty acid content $(\%$ of total Fatty acids) } \\
$\Sigma$ unsaturated fatty acids & $82.85 \pm 0.14$ & $83.83 \pm 4.26$ \\
Oleic acid C18:1n-9 & $22.76 \pm 0.02$ & $21.39 \pm 0.02$ \\
Linoleic acid C18:2n-6 & $54.56 \pm 0.14$ & $56.77 \pm 0.57$ \\
$\alpha$-Linolenic acid C18:3n-3 & $1.54 \pm 0.02$ & $0.49 \pm 0.01$ \\
& Tocopherol content (mg/kg) & $92.00 \pm 7.00$ \\
$\gamma$ - Tocopherol & undetectable & $(220.88 \pm 16.78 \mu \mathrm{mol} / \mathrm{L})$ \\
& & $202.00 \pm 17.00$ \\
$\alpha$-Tocopherol & undetectable & $(468.67 \pm 39.44 \mu \mathrm{mol} / \mathrm{L})$ \\
Total Tocopherols Content & undetectable & $274.00 \pm 24.00$ \\
\hline
\end{tabular}


Table 1. Cont.

\begin{tabular}{ccc}
\hline & NSO & MTSO \\
\hline Polyphenol content & (mg equivalent quercetin/kg of oil) \\
Thymoquinone & $7.00 \pm 0.58$ & Undetectable \\
Vanillin & $2.30 \pm 0.06$ & Undetectable \\
Homovanillic Acid & $1.90 \pm 0.00$ & Undetectable \\
Quercetin & $1.30 \pm 0.02$ & $1.20 \pm 0.04$ \\
Apigenin & undetectable & $0.90 \pm 0.10$ \\
\hline Data are represented as mean \pm SD. NSO: Nigella seed oils; MTSO: Milk Thistle seed oils.
\end{tabular}

The analysis of unsaturated fatty acids showed a relatively similar composition of NSO and MTSO except for $\alpha$-linolenic acid (C18:3 n-3). In MTSO, both $\alpha$-tocopherol and $\gamma$-tocopherol were detected (unlike NSO). $\alpha$-tocopherol, a potent antioxidant, was the most abundant though $(202 \pm 17 \mathrm{mg} / \mathrm{kg})$.

Polyphenols are known to have potent neuroprotective properties $[15,16]$, thus polyphenols in NSO and MTSO were determined. Our results showed a high level of thymoquinone in NSO followed by vanillin, homovanillic acid, and quercetin. In MTSO, only quercetin and apigenin were detected (Table 1).

\subsubsection{Antioxidant Activities of NSO and MTSO}

The antioxidant activities of NSO and MTSO are represented in Figure 1.

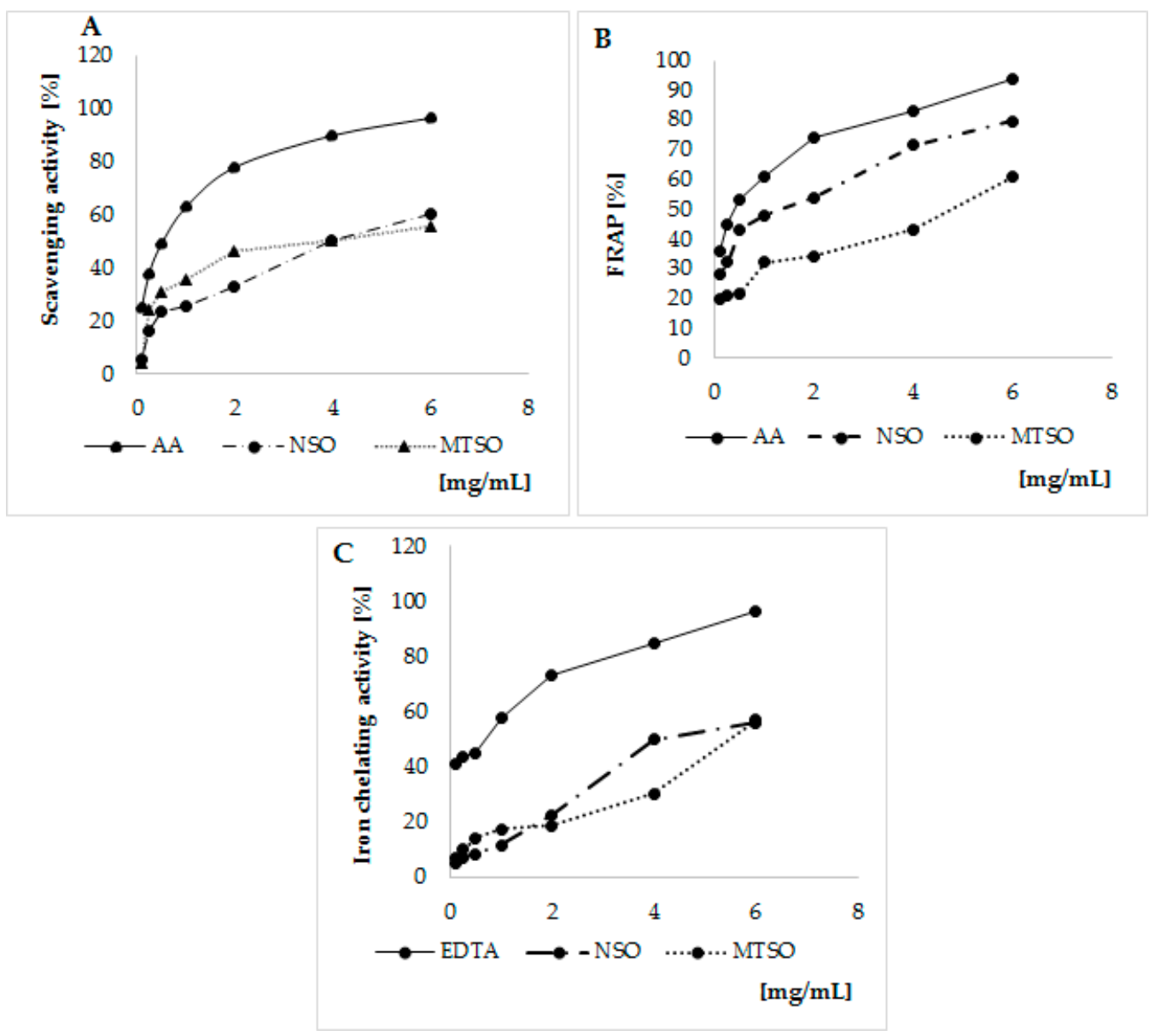

Figure 1. Antioxidant activities of NSO and MTSO. (A) DPPH assay. (B) FRAP assay. (C) Iron chelating Assay. NSO: Nigella seed oils; MTSO: Milk Thistle seed oils; EDTA: Ethylenediaminetetraacetic acid; AA: Ascorbic acid; FRAP: Ferric Reducing Antioxidant Power; DPPH 2,2-diphenyl-1-picrylhydrazyl. 
Both NSO and MTSO exhibit free radicals scavenging activity as shown by DPPH test. Their activities were lesser than the AA (Figure 1A). To compare the scavenging activity of the oils, the half-maximal inhibitory concentration (IC50) (volume of seed oils required to lower the initial DPPH concentration by $50 \%$ ) was determined from the dose-response curve (Table 2).

Table 2. IC50 values of DPPH, FRAP, and iron chelating activity of NSO and MTSO.

\begin{tabular}{cccc}
\hline & \multicolumn{3}{c}{ IC50 Values $(\mathbf{m g} / \mathbf{m L})$} \\
\hline Samples & DPPH & FRAP & Iron Chelating \\
\hline NSO & $4.11 \pm 0.16$ & $1.85 \pm 0.18$ & $4.86 \pm 0.11$ \\
\hline MTSO & $4.30 \pm 0.33$ & $4.53 \pm 0.23$ & $5.75 \pm 0.24$ \\
\hline EDTA (standard) & - & - & $0.60 \pm 0.09$ \\
\hline AA (standard) & $0.81 \pm 0.27$ & $0.41 \pm 0.16$ & - \\
\hline
\end{tabular}

Data are represented as mean \pm SD. IC50: Half-maximal inhibitory concentration; NSO: Nigella seed oils MTSO: Milk Thistle seed oils; EDTA: Ethylenediaminetetraacetic acid; AA: Ascorbic acid; FRAP: Ferric Reducing Antioxidant Power; DPPH 2,2-diphenyl-1-picrylhydrazyl.

Our result indicates a free radical scavenging activity of NSO similar to MTSO. IC50 values were $4.11 \pm 0.16$ and $4.30 \pm 0.33(\mathrm{mg} / \mathrm{mL})$, in NSO and MTSO, respectively.

The reducing power of each oil measured by FRAP was investigated along with AA used as standard reference (Figure 1B). NSO showed higher reducing power regarding MTSO. IC50 value were $1.85 \pm 0.18$ and $4.53 \pm 0.23(\mathrm{mg} / \mathrm{mL})$ in NSO and MTSO, respectively (Table 2). In addition, a slightly higher iron chelating activity was observed in NSO treated cells compared to MTSO (Figure 1C and Table 2).

Although our results indicate potential antioxidant capacity of the two studied seed oils, NSO showed the highest antioxidant activities.

\subsection{Evaluation of the Cytotoxicity and the Pro-Oxidative Activity of $7 \beta-O H C$}

\subsubsection{The Effect of $7 \beta-\mathrm{OHC}$ on Cell Viability and Proliferation}

The MTT assay is widely used to study mitochondrial activity, cell viability, and /or cell proliferation. The effect of $7 \beta-\mathrm{OHC}$ (compared to $\mathrm{H}_{2} \mathrm{O}_{2}$ ) on cell viability is shown in Figure 2.
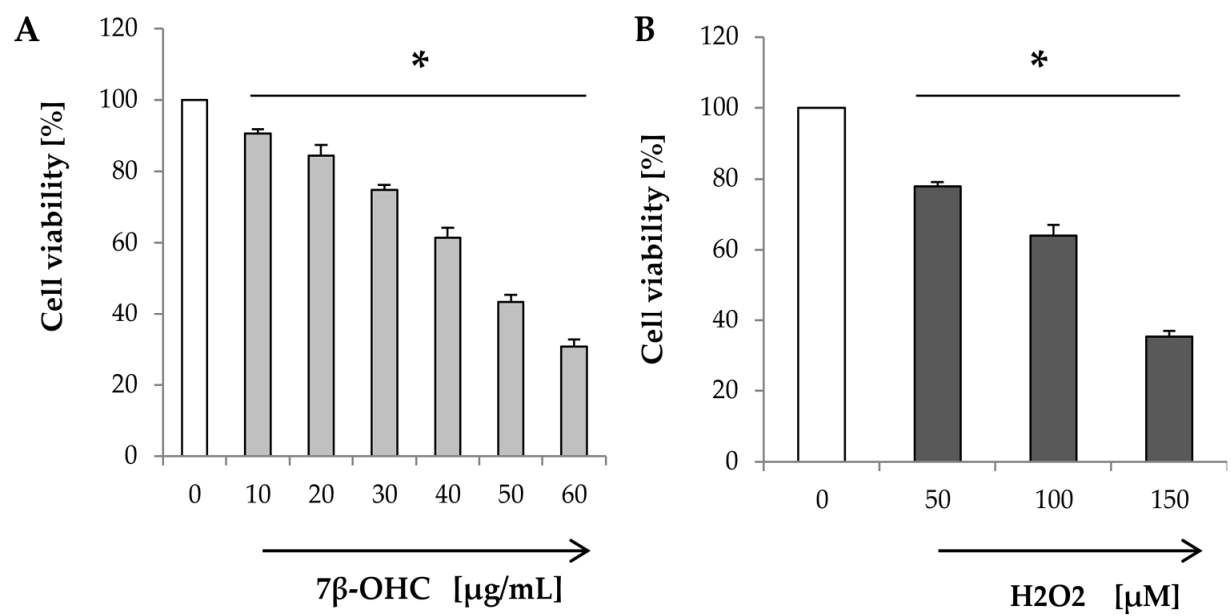

Figure 2. Effect of $7 \beta-\mathrm{OHC}$ on cell viability and proliferation. (A) MTT assay: Cells were incubated with different concentrations of $7 \beta-\mathrm{OHC}(10-60 \mu \mathrm{g} / \mathrm{mL})$ for $24 \mathrm{~h}$. (B) MTT assay: Cells were incubated with different concentrations of $\mathrm{H}_{2} \mathrm{O}_{2}(50-150 \mu \mathrm{M})$ for $24 \mathrm{~h}$. Data are represented as mean \pm SD. $7 \beta$-OHC: $7 \beta$-hydroxycholesterol; $\mathrm{H}_{2} \mathrm{O}_{2}: \mathrm{Hydrogen}$ peroxide. Statistical analyses were performed using the Mann-Whitney test or student $\mathrm{t}$ test. * Statistical differences were significant between the control and $7 \beta-\mathrm{OHC}$ or $\mathrm{H}_{2} \mathrm{O}_{2}$-treated cells $(p<0.05)$. 
Our results showed that increasing concentrations of $7 \beta-\mathrm{OHC}$ were toxic in a dosedependent manner (Figure 2A). Similar results were obtained with $\mathrm{H}_{2} \mathrm{O}_{2}$ (used as a positive control of toxicity) (Figure 2B).

In the presence of $7 \beta-\mathrm{OHC}(40 \mu \mathrm{g} / \mathrm{mL})$, cell viability was significantly reduced to $61.53 \pm 2.76(\%)$ compared to control. A comparable effect was obtained with $\mathrm{H}_{2} \mathrm{O}_{2}$ $(100 \mu \mathrm{M})$.

Since $7 \beta-O H C(40 \mu \mathrm{g} / \mathrm{mL})$ induced a moderate toxicity $(40 \%)$ in SH-SY5Y cells, this concentration was chosen in the rest of the study.

\subsubsection{The effect of $7 \beta-\mathrm{OHC}$ on Intracellular ROS Production}

Numerous studies reported pro-oxidative activities of oxysterols including $7 \beta-\mathrm{OHC}[37-40]$. Thus, we intended to evaluate the ability of $7 \beta-\mathrm{OHC}(40 \mu \mathrm{g} / \mathrm{mL})$ to induce intracellular ROS production in comparison with $\mathrm{H}_{2} \mathrm{O}_{2}(100 \mu \mathrm{M})$ using $\mathrm{H}_{2}$ DCFDA fluorescence assay. Results are shown in Figure 3.

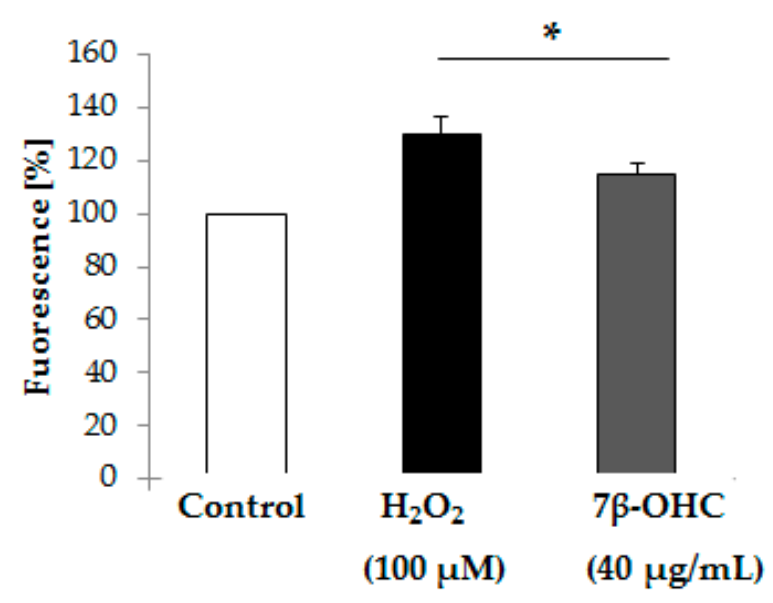

Figure 3. Effect of $7 \beta-\mathrm{OHC}$ on Intracellular ROS production by $\mathrm{H}_{2} \mathrm{DCFDA}$ fluorescence assay. Data are represented as mean \pm SD. ROS: reactive oxygen species; $\mathrm{H}_{2}$ DCFDA: $2^{\prime} 7^{\prime}$-dichlorofluorescein diacetate; DCF: 2'7'-dichlorofluorescein; $7 \beta-\mathrm{OHC}$ : $7 \beta$-hydroxycholesterol; $\mathrm{H}_{2} \mathrm{O}_{2}$ : Hydrogen peroxide. Statistical analyses were performed using the Mann-Whitney test or student $\mathrm{t}$ test. * Statistical differences were significant between the control and $7 \beta-\mathrm{OHC}$ or $\mathrm{H}_{2} \mathrm{O}_{2}$-treated cells $(p<0.05)$.

Our results indicate a significant increase in ROS production in $7 \beta-\mathrm{OHC}$-treated cells, compared to control. The same result was obtained after exposing cells to $\mathrm{H}_{2} \mathrm{O}_{2}(100 \mu \mathrm{M})$. (Figure 3). These findings are in favor of the pro-oxidative activity of $7 \beta-\mathrm{OHC}$.

\subsubsection{The Effect of $7 \beta-\mathrm{OHC}$ on Cellular Oxidative Stress}

The effect of $7 \beta-\mathrm{OHC}$ on redox status was evaluated through the determination of the enzymatic and non-enzymatic antioxidants, lipid, and protein oxidation products. Results are represented in Tables 3-5.

Under the treatment with $7 \beta-\mathrm{OHC}(40 \mu \mathrm{g} / \mathrm{mL})$, a significant decrease of GPx and SOD activities was observed $(p<0.05)$, compared to untreated and vehicle (EtOH)-treated cells. This may reflect either an alteration of the enzymatic antioxidant defense system in viable cells or the loss of the enzymatic activities due to cell death.

Thiol groups, known to play an important role in the protection against free radicals, were also found to be decreased in cells treated with $7 \beta-\mathrm{OHC}$ (Table 3). Our findings imply an insufficiency of the enzymatic and non-enzymatic antioxidant system defense regarding $7 \beta-\mathrm{OHC}$.

Compared to untreated or vehicle-treated cells, lipid, and protein oxidation products (MDA, CD, and CP) were found at higher level in cells treated with $7 \beta-\mathrm{OHC}$ supporting thereby the pro-oxidative property of this oxysterol. 


\subsection{The Cytoprotective Study of NSO and MTSO}

3.3.1. The Effect of NSO and MTSO Associated with $7 \beta-\mathrm{OHC}$ on Cell Viability and Proliferation

The effect of NSO and MTSO, associated with $7 \beta-\mathrm{OHC}$, on cell viability and proliferation are shown in Figure 4.
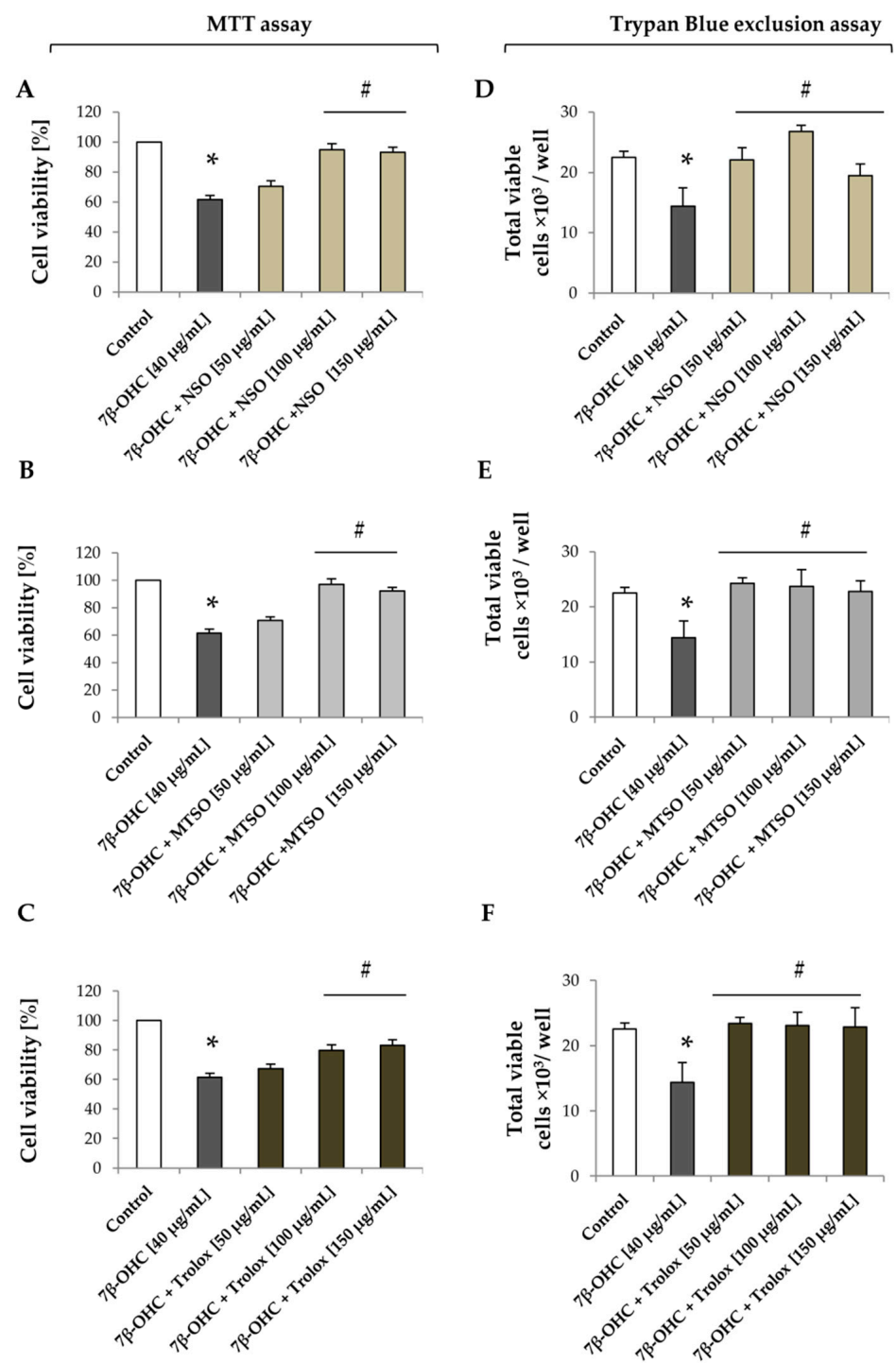

Figure 4. Effect of NSO and MTSO associated with $7 \beta-\mathrm{OHC}$ on cell viability and proliferation. (A) effect of NSO $(50-150 \mu \mathrm{g} / \mathrm{mL})$ associated with $7 \beta-\mathrm{OHC}(40 \mu \mathrm{g} / \mathrm{mL})$ on cell viability and proliferation by the MTT assay. (B) effect of MTSO $(50-150 \mu \mathrm{g} / \mathrm{mL})$ associated with $7 \beta-\mathrm{OHC}(40 \mu \mathrm{g} / \mathrm{mL})$ on cell viability and proliferation by the MTT assay. (C) effect of trolox (50-150 $\mu \mathrm{g} / \mathrm{mL})$ associated with $7 \beta-\mathrm{OHC}(40 \mu \mathrm{g} / \mathrm{mL})$ on cell viability and proliferation by the MTT assay. (D) effect of NSO $(50-150 \mu \mathrm{g} / \mathrm{mL})$ associated with $7 \beta-\mathrm{OHC}(40 \mu \mathrm{g} / \mathrm{mL})$ on cell viability and proliferation by the trypan blue exclusion assay. (E) effect of MTSO (50-150 $\mu \mathrm{g} / \mathrm{mL})$ associated with $7 \beta-\mathrm{OHC}(40 \mu \mathrm{g} / \mathrm{mL})$ on cell viability and proliferation by the trypan blue exclusion assay. (F) effect of trolox $(50-150 \mu \mathrm{g} / \mathrm{mL})$ associated with $7 \beta-\mathrm{OHC}(40 \mu \mathrm{g} / \mathrm{mL})$ on cell viability and proliferation by the trypan blue exclusion assay. Data are represented as mean \pm SD. $7 \beta-O H C: 7 \beta$-hydroxycholesterol; NSO: Nigella sativa seed oil; MTSO: Milk Thistle seed oil; MTT: Methyl thiazolyldiphenyl-Tetrazolium Bromide. Statistical analyses were performed using the Mann-Whitney test or student $t$ test. * Statistical differences were significant between the control and or $7 \beta-\mathrm{OHC}$-treated cells $(p<0.05)$. ${ }^{\text {N }}$ Statistical differences were significant between $7 \beta-\mathrm{OHC}$-treated cells and $7 \beta-\mathrm{OHC}+(\mathrm{NSO}$ or MTSO) -treated cells $(p<0.05)$. 
Our results indicate a decrease in cells viability and proliferation (by MTT assay) under treatment with $7 \beta-\mathrm{OHC}(40 \mu \mathrm{g} / \mathrm{mL})$ (Figure $4 \mathrm{~A})$. This observation was also confirmed by the trypan blue exclusion assay. Compared to untreated cells, the number of total viable cells was significantly reduced to $14 \pm 3 \times 103$ cell / well in the presence of $7 \beta-\mathrm{OHC}$ $(40 \mu \mathrm{g} / \mathrm{mL})$ (Figure 4E). Interestingly, treatment with NSO, MTSO, or Trolox (used as a positive control) have restored cell viability and proliferation, especially at $100 \mu \mathrm{g} / \mathrm{mL}$ (Figure 4).

A similar protective effect was observed against $\mathrm{H}_{2} \mathrm{O}_{2}$-induced cytotoxicity (Figures in Supplementary Materials).

These data led us to assess further the mechanism by which both oils afford cytoprotection via the evaluation of oxidative stress biomarkers and the characterization of cell death.

3.3.2. The Effect of NSO and MTSO Associated with $7 \beta-\mathrm{OHC}$ on the Enzymatic and Non-Enzymatic Cellular Antioxidants Defense System

The levels of enzymatic and non-enzymatic antioxidants in the presence of NSO and MTSO (associated or not with $7 \beta-\mathrm{OHC}(40 \mu \mathrm{g} / \mathrm{mL})$ ) are represented in Table 3.

Table 3. Levels of enzymatic and non-enzymatic antioxidants under pre-treatment with NSO or MTSO.

\begin{tabular}{cccc}
\hline & SOD (\% Control) & GPx (\% Control) & $\begin{array}{c}\text { Thiols } \\
(\boldsymbol{\mu m o l} / \mathbf{m g} \text { of Protein) }\end{array}$ \\
\hline Control & $100 \pm 0.00$ & $100 \pm 0.00$ & $0.95 \pm 0.01$ \\
$($ EtOH 0.2\%) & $97.85 \pm 0.76$ & $91.18 \pm 9.36$ & $0.92 \pm 0.14$ \\
$(\mathrm{DMSO} 0.4 \%)$ & $98.17 \pm 2.34$ & $98.25 \pm 4.18$ & $0.97 \pm 0.09$ \\
$(\mathrm{EtOH}+\mathrm{DMSO})$ & $97.88 \pm 1.50$ & $99.18 \pm 9.28$ & $0.95 \pm 0.01$ \\
NSO $(100 \mu \mathrm{g} / \mathrm{mL})$ & $99.30 \pm 4.18$ & $97.41 \pm 5.40$ & $0.94 \pm 0.02$ \\
MTSO $(100 \mu \mathrm{g} / \mathrm{mL})$ & $101.47 \pm 2.78$ & $96.81 \pm 1.14$ & $0.98 \pm 0.07$ \\
$7 \beta-\mathrm{OHC}(40 \mu \mathrm{g} / \mathrm{mL})$ & $34.73 \pm 1.43^{*}$ & $56.42 \pm 5.25^{*}$ & $0.48 \pm 0.08^{*}$ \\
$7 \beta-\mathrm{OHC}+\mathrm{NSO}(100 \mu \mathrm{g} / \mathrm{mL})$ & $47.77 \pm 0.89 \#$ & $75.65 \pm 5.10$ & $0.45 \pm 0.08$ \\
$7 \beta-\mathrm{OHC}+$ MTSO $(100 \mu \mathrm{g} / \mathrm{mL})$ & $109.63 \pm 7.73 \#$ & $106.26 \pm 10.30 \#$ & $0.59 \pm 0.04$ \\
\hline
\end{tabular}

Data are represented as mean \pm SD. $7 \beta$-OHC: $7 \beta$-hydroxycholesterol; SOD: superoxide dismutase; GPx: glutathione peroxidase; NSO: Nigella sativa seed oil; MTSO: Milk Thistle seed oil; DMSO: dimethyl sulfoxide; EtOH: Ethanol. Statistical analyses were performed using the Mann-Whitney test or student $t$ test. * Statistical differences were significant between the control and vehicle $(\mathrm{EtOH})$ or $7 \beta-\mathrm{OHC}$-treated cells $(p<0.05)$. \# Statistical differences were significant between $7 \beta-\mathrm{OHC}$-treated cells and $7 \beta-\mathrm{OHC}+(\mathrm{NSO}$ or MTSO) -treated cells $(p<0.05)$.

Under the treatment with NSO and MTSO alone, GPx and SOD activities were relatively similar to those of untreated or vehicle (DMSO)-treated cells. In the presence of $7 \beta-\mathrm{OHC}$, both GPx and SOD activities were decreased as described before. However, an increase in those activities was observed in $7 \beta-\mathrm{OHC}+\mathrm{NSO}$ or MTSO -treated cells (Table 3 ). Our results showed also a higher enzymatic activity in $7 \beta-\mathrm{OHC}+\mathrm{MTSO}(100 \mu \mathrm{g} / \mathrm{mL})-$ treated cells regarding control. This could reflect an enhancement of cell proliferation. Although thiol groups were decreased in cells treated with $7 \beta-\mathrm{OHC}$, neither NSO nor MTSO were able to modulate the production of these molecules.

3.3.3. The Effect of NSO and MTSO Associated with 7 $\beta-\mathrm{OHC}$ on the Lipid Peroxidation Levels

The effects of NSO and MTSO (associated or not with $7 \beta-\mathrm{OHC}$ ) on the lipid peroxidation biomarkers levels are shown in Table 4.

No significant difference in MDA and CD levels was seen between control or vehicle (DMSO) and NSO or MTSO-treated cells. Although increased levels of those products were found in the presence of $7 \beta-\mathrm{OHC}(40 \mu \mathrm{g} / \mathrm{mL})$, a marked reduction of MDA and CD concentration was observed in cells pre-treated with MTSO or NSO $(100 \mu \mathrm{g} / \mathrm{mL})($ Table 4). 
Table 4. Levels of lipid peroxidation biomarkers under pre-treatment with NSO or MTSO.

\begin{tabular}{ccc}
\hline & $\begin{array}{c}\text { MDA } \\
(\mu \text { mol/mg of Protein })\end{array}$ & $\begin{array}{c}\text { CD } \\
(\mu \text { mol/mg of Protein })\end{array}$ \\
\hline Control & $68.09 \pm 3.43$ & $0.55 \pm 0.83$ \\
$($ EtOH 0.2\%) & $70.05 \pm 5.70$ & $0.40 \pm 0.10$ \\
$(\mathrm{DMSO} 0.4 \%)$ & $73.43 \pm 1.11$ & $0.54 \pm 0.04$ \\
(EtOH $+\mathrm{DMSO})$ & $71.32 \pm 0.43$ & $0.56 \pm 0.04$ \\
MTSO $(100 \mu \mathrm{g} / \mathrm{mL})$ & $69.96 \pm 2.60$ & $0.59 \pm 0.03$ \\
$7 \beta-\mathrm{H}$ (100 $(40 \mu \mathrm{mL} / \mathrm{mL})$ & $70.93 \pm 2.38$ & $0.44 \pm 0.01$ \\
$7 \beta-\mathrm{OHC}+\mathrm{NSO}(100 \mu \mathrm{g} / \mathrm{mL})$ & $99.39 \pm 2.50^{*}$ & $0.89 \pm 0.07^{*}$ \\
$7 \beta-\mathrm{OHC}+\mathrm{MTSO}(100 \mu \mathrm{g} / \mathrm{mL})$ & $79.64 \pm 1.60^{\#}$ & $0.52 \pm 0.12^{\#}$ \\
\hline
\end{tabular}

Data are the mean \pm SD. 7 $\beta$-OHC: $7 \beta$-hydroxycholesterol; MDA: malondialdehyde; CDs: conjugated dienes; NSO: Nigella sativa seed oil; MTSO: Milk Thistle seed oil; DMSO: dimethyl sulfoxide; EtOH: Ethanol. Statistical analyses were performed using the Mann-Whitney test or student $t$ test. ${ }^{*}$ Statistical differences were significant between the control and vehicle $(\mathrm{EtOH})$ or $7 \beta-\mathrm{OHC}$-treated cells $(p<0.05)$. \# Statistical differences were significant between $7 \beta-\mathrm{OHC}$-treated cells and $7 \beta-\mathrm{OHC}+(\mathrm{NSO}$ or MTSO $)$-treated cells $(p<0.05)$.

3.3.4. The Effect of NSO and MTSO Associated with $7 \beta-\mathrm{OHC}$ on the Protein Oxidation and Nitrotyrosinantion

To investigate the cytoprotective effects of NSO and MTSO on proteins; the levels of $\mathrm{CP}$ and nitrotyrosine were evaluated (Table 5 and Figure 5).

No significant difference in CP level was seen between control or vehicle (DMSO) and NSO or MTSO-treated cells. However, a significant increase in CP concentration was observed under treatment with $7 \beta-\mathrm{OHC}(40 \mu \mathrm{g} / \mathrm{mL})$. The pre-treatment with seeds oils, especially with MTSO $(100 \mu \mathrm{g} / \mathrm{mL})$, showed a decrease of CP formation (Table 5), supporting further the cytoprotective activity of MTSO against oxidative damages.

The study of protein nitrotyrosination affords information on the production of reactive nitrogen species (RNS), especially peroxynitrite radical (ONOO-) [41]. In our study, $7 \beta$-OHC-treated cells showed a significant increase of nitrotyrosine level compared to control, indicating increased RNS production $(1.82 \pm 0.08$ vs $0.77 \pm 0.06$ (A.U), respectively). Although no significant reduction of protein nitrotyrosination was seen under pre-treatment with NSO. Interestingly, a significant decrease of nitrotyrosine concentration was observed in cells pre-treated with MTSO compared to $7 \beta$-OHC-treated cells alone $(p<0.05)$ (Figure 5).

Table 5. Levels of protein oxidation biomarker under pre-treatment with NSO or MTSO.

\begin{tabular}{|c|c|}
\hline & $\begin{array}{c}\mathrm{CP} \\
(\mu \mathrm{mol} / \mathrm{mg} \text { of Protein) }\end{array}$ \\
\hline Control & $0.13 \pm 0.01$ \\
\hline$(\mathrm{EtOH} 0.2 \%)$ & $0.12 \pm 0.02$ \\
\hline (DMSO 0.4\%) & $0.15 \pm 0.01$ \\
\hline$(\mathrm{EtOH}+\mathrm{DMSO})$ & $0.12 \pm 0.02$ \\
\hline NSO $(100 \mu \mathrm{g} / \mathrm{mL})$ & $0.13 \pm 0.01$ \\
\hline MTSO $(100 \mu \mathrm{g} / \mathrm{mL})$ & $0.12 \pm 0.02$ \\
\hline $7 \beta-\mathrm{OHC}(40 \mu \mathrm{g} / \mathrm{mL})$ & $0.39 \pm 0.04^{*}$ \\
\hline $7 \beta-\mathrm{OHC}+\mathrm{NSO}(100 \mu \mathrm{g} / \mathrm{mL})$ & $0.28 \pm 0.03$ \\
\hline $7 \beta-\mathrm{OHC}+\mathrm{MTSO}(100 \mu \mathrm{g} / \mathrm{mL})$ & $0.17 \pm 0.02^{\#}$ \\
\hline $\begin{array}{l}\text { Data are represented as mean } \pm \text { SD. } 7 \beta-O H C \\
\text { sativa seed oil; MTSO: Milk Thistle seed oil; D } \\
\text { performed using the Mann-Whitney test or s } \\
\text { control and vehicle }(\mathrm{EtOH}) \text { or } 7 \beta-\mathrm{OHC} \text {-treate } \\
7 \beta-\mathrm{OHC} \text {-treated cells and } 7 \beta-\mathrm{OHC}+(\mathrm{NSO} \text { or }\end{array}$ & $\begin{array}{l}\text { CP: carbonylated protei } \\
\text { EtOH: Ethanol. Statisti } \\
\text { differences were signifi } \\
\text { ical differences were sig } \\
0.05 \text { ). }\end{array}$ \\
\hline
\end{tabular}



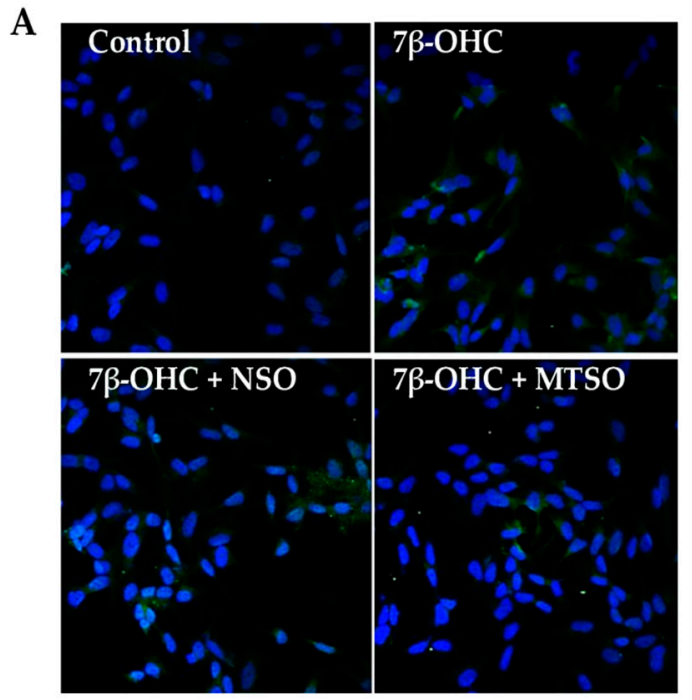

B

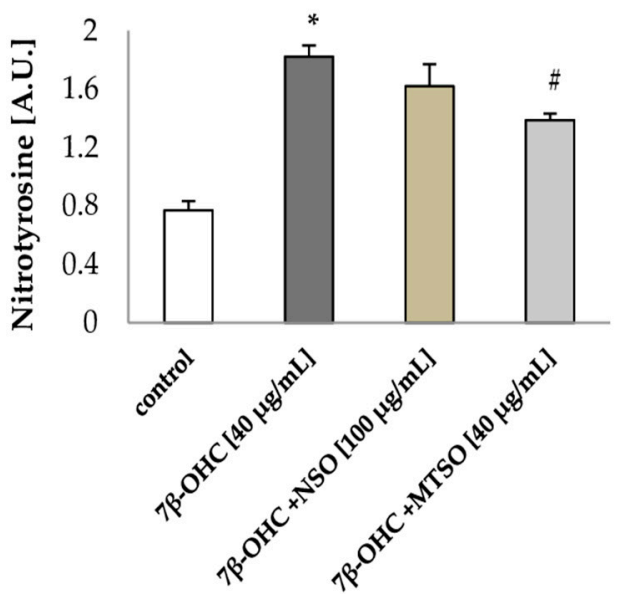

Figure 5. The cytoprotective effects of NSO and MTSO to proteins. (A) Confocal immunofluorescence microscopy observation of Nitrotyrosine (green fluorescence) with DAPI-stained nuclei (blue fluorescence) in SHSY5Y cells. (B) Nitrotyrosine quantification. Data are shown as mean \pm SD. A.U: arbitrary units; 7 $\beta$-OHC: 7 $\beta$-hydroxycholesterol; NSO: Nigella sativa seed oil; MTSO: Milk Thistle seed oil. Statistical analyses were performed using the Mann-Whitney test or student $\mathrm{t}$ test. ${ }^{*}$ Statistical differences were significant between the control and $7 \beta-O H C$-treated cells $(p<0.05)$. ${ }^{\#}$ Statistical differences were significant between the $7 \beta-\mathrm{OHC}$-treated cells and $7 \beta-\mathrm{OHC}+(\mathrm{NSO}$ or MTSO)-treated cells $(p<0.05)$.

\subsubsection{NSO and MTSO Protects against Apoptosis Induced by $7 \beta-\mathrm{OHC}$}

Based on the MTT and trypan blue assays data, we investigated further the activation of the pro-apoptotic machinery by the detection of cleaved caspase 3 under the pre-treatment with NSO and MTSO. Results are shown in Figure 6.

A

B
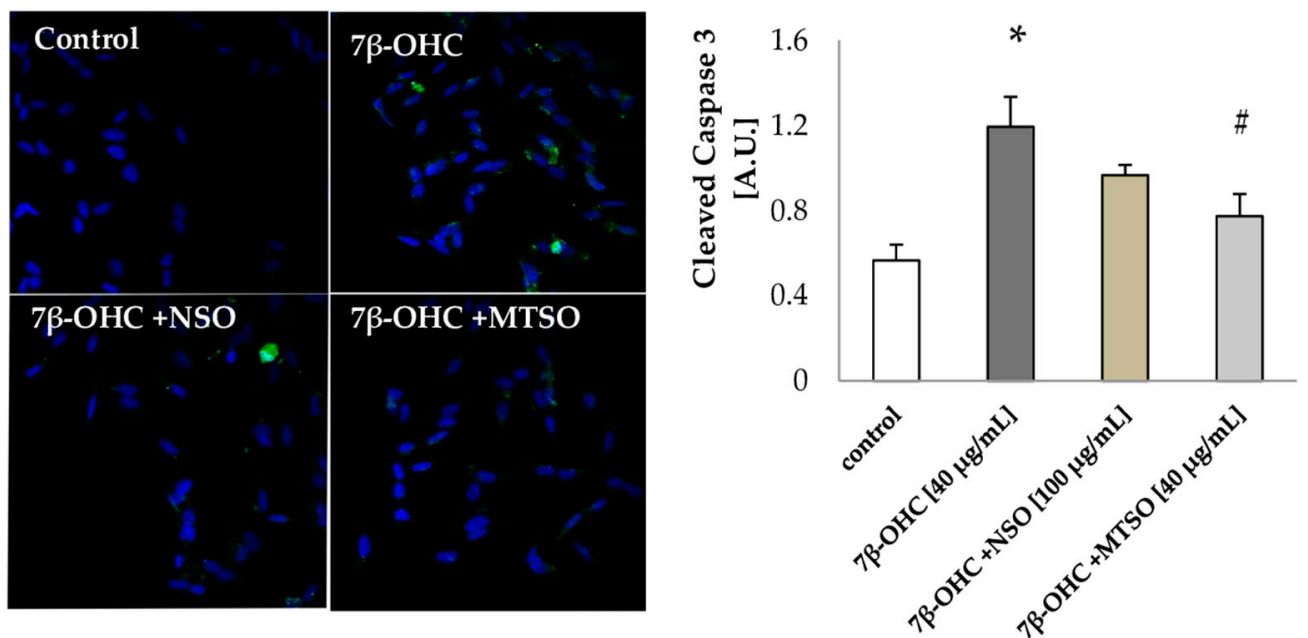

Figure 6. The cytoprotective effects of NSO and MTSO against cell death (A) Confocal immunofluorescence microscopy observation of cleaved caspase 3 (green fluorescence) with DAPI-stained nuclei (blue fluorescence) in SHSY5Y cells. (B) Cleaved caspase 3 quantification. Data are shown as mean \pm SD. A.U: arbitrary units; $7 \beta-O H C$ : $7 \beta$-hydroxycholesterol; NSO: Nigella sativa seed oil; MTSO: Milk Thistle seed oil. Statistical analyses were performed using the Mann-Whitney test or student $\mathrm{t}$ test. ${ }^{*}$ Statistical differences were significant between the control and $7 \beta-\mathrm{OHC}$-treated cells $(p<0.05)$. \# Statistical differences were significant between the 7 $\beta-\mathrm{OHC}$-treated cells and $7 \beta-\mathrm{OHC}+(\mathrm{NSO}$ or MTSO)-treated cells $(p<0.05)$. 
Our findings indicate that $7 \beta-\mathrm{OHC}$ triggers apoptotic death in SHSY5Y cells via the activation of caspase $3(p<0.05)$. A marked reduction of cleaved-caspase 3 was obtained in cells pre-treated with MTSO $(100 \mu \mathrm{g} / \mathrm{mL})(p<0.05)$. Although pre-treatment with NSO also showed a slight reduction of cleaved-caspase 3 , the result was statistically non-significant.

The overall results suggest that NSO and, to a higher extent, MTSO can protect SH-SY5Y cells against 7 $\beta$-OHC-induced oxidative damages and cell death.

\section{Discussion}

It is believed that oxysterols play a crucial role in the progression of chronic diseases including neurodegenerative diseases. These molecules can cross the blood-brain barrier and accumulate in the plasma membrane and inside the cell [42]. Some oxysterols, including $7 \beta-\mathrm{OHC}$, exhibit pro-oxidative and pro-apoptotic properties [37-40].

In $\mathrm{AD}, \mathrm{PD}$, and $\mathrm{HD}$ conditions high levels of $7 \beta-\mathrm{OHC}$ were reported. Effective intervention strategies, including antioxidants therapies, could be a useful tool to oppose the pro-oxidative and pro-apoptotic activities of oxysterols.

In this line, our study was designed to investigate; (i) the ability of $7 \beta-\mathrm{OHC}$ to trigger oxidative stress and cell death in human neuroblastoma cells (SH-SY5Y) (ii) the capacity of Nigella sativa and Milk thistle seed oils (NSO and MTSO, respectively) to oppose $7 \beta$-OHC-induced side effects. Overall, our study establishes that $7 \beta-\mathrm{OHC}$ induces cell death and several oxidative damages on SH-SY5Y cells. Alongside, it probably suppresses cell proliferation, shown by the reduction of cell viability. NSO and, most importantly, MTSO were capable of attenuating $7 \beta-O H C$-induced toxicity. The cytoprotective effects of NSO and MTSO are likely related to ROS scavenging as well as the enhancement of cell proliferation.

The analysis of NSO and MTSO composition indicates that both oils represent good sources of essential fatty acids. In agreement with our results, studies reported that NSO and MTSO contain important amounts of linoleic, oleic, and $\alpha$-linolenic acids [19,25]. In our study, a high concentration of thymoquinone, a potent antioxidant compound, was detected in NSO. This is in harmony with the previous studies $[20,21,25]$. Our results indicate the presence of both $\alpha$ - and $\gamma$ - tocopherols in MTSO. Tocopherol profile is important to define the potential health benefits of vegetable oils and $\alpha$-tocopherol is considered as the most biologically active isomer [43]. It is noteworthy that tocopherols and polyphenols can cross the blood-brain barrier. Moreover, these compounds showed potent neuroprotective properties [15,16], which is in favor of its consumption. In our study, the antioxidant activity of the oils, evaluated by DPPH, FRAP, and iron chelating assays, demonstrated an antioxidant potential of NSO and MTSO, which reinforced our interest to study their cytoprotective effects in vitro.

The cytotoxicity of 7 $\beta-\mathrm{OHC}(40 \mu \mathrm{g} / \mathrm{mL})$ on SH-SY5Y cells line was manifested by a reduction of cell viability and proliferation. Besides, numerous side effects were observed under treatment with this compound, consisting of apoptosis induction, ROS overproduction, impaired enzymatic and non-enzymatic antioxidants, and the increase of end products of lipid peroxidation, protein oxidation, and nitrotyrosination. Interestingly, the pre-treatment with NSO or MTSO $(100 \mu \mathrm{g} / \mathrm{mL})$ showed a marked attenuation of $7 \beta-\mathrm{OHC}$-induced toxicity, implying a potential cytoprotective effect of NSO an MTSO.

In the literature, several studies reported the cytotoxicity of $7 \beta-\mathrm{OHC}$ in different cell lines including $158 \mathrm{~N}$ and SK-N-BE $[37,40,44,45]$. Oxysterols are natural components of the human body. At low concentration, these molecules mediate many physiological functions within cells, such as enhancing the expression of inflammatory mediators (Interleukin 8) [46,47], modulating cholesterol homeostasis, and membrane permeability [48]. However, at higher concentration, some oxysterols can induce harmful effects. Indeed, anti-proliferative and pro-apoptotic activities of $7 \beta-\mathrm{OHC}$ were reported in different cell lines including murine oligodendrocytes (158N), monoblastic cell line (U937), and human liver cancer cell line (HepG2) [40,47,49-51]. In our study, an induction of apoptotic cell death by $7 \beta-\mathrm{OHC}$ was also observed. Besides, a reduction of cell viability and proliferation 
was seen under treatment with this compound, which is in harmony with the previous studies.

It is noteworthy that some oxysterols exhibit pro-oxidant property. Under treatment with $7 \beta-\mathrm{OHC}$, high level of lipid and protein oxidation products (MDA, CD, and $\mathrm{CP}$ ) as well as an increase of antioxidant enzymatic activities was reported [37,45]. These data are in partial agreement with our results. In the literature, few papers reported the effect of oxysterols, especially $7 \beta-\mathrm{OHC}$, on the antioxidant enzymes activities. In addition, results are disparate. While in vitro studies suggested an increase of the antioxidant enzymes activities, under treatment with oxysterols, [37,45], a recent in vivo study reported a decrease of these activities [52]. In rat red blood cells exposed to different oxysterols ( $5 \alpha, 6 \alpha$-Epoxyphytosterols and $5 \alpha, 6 \alpha$-Epoxycholesterol), a significant decrease of the antioxidant enzymes activities (GPx and SOD but not catalase) was observed [52]. Besides, it has been reported that increased levels of oxysterols (25-hydroxy-, $7 \alpha$-hydroxy-, and 7ketocholesterol) and MDA were associated with the decrease of catalase and SOD activities in rats exposed to $\mathrm{H}_{2} \mathrm{O}_{2}$ [53]. However, it is difficult to conclude whether the deficiency in enzymatic activity was directly triggered by oxysterols or $\mathrm{H}_{2} \mathrm{O}_{2}$. In the present study, the decrease of antioxidant enzyme activities could be a cause, but also a consequence, of the accumulated ROS and RNS. In fact, nitrotyrosine detection is believed to be a biomarker of RNS generation and protein damages [54-56]. The protein-tyrosine-nitration can affect protein structure and function leading to macromolecules damages such as inactivation of certain enzymes including catalase and MnSOD [57,58]. Therefore, we can suggest that the loss of SOD and GPx activities in our study is caused by the increase of protein nitrotyrosination observed in 7 $\beta$-OHC-treated cells. On the other hand, under physiological conditions, ROS are removed by the antioxidant system, but probably during mild and prolonged oxidative stress, the ROS concentration in cells reaches a threshold that can trigger downregulation of the antioxidant enzymes.

As reported belong, NSO and MTSO showed cytoprotective effects against the cytotoxicity mediated by $7 \beta-\mathrm{OHC}$. Both oils, especially MTSO, were able to reduce lipid and protein oxidation, inhibit caspase 3 activation, and improve the antioxidant enzyme activities. In addition, these oils enhanced SH-SY5Y cells proliferation. In the literature, NSO and MTSO are known to have antioxidant activities, since these oils contain several bioactive components including polyphenols and tocopherols [20-22]. As such, milk thistle extract was reported to promote differentiation and neuronal survival as well as protects rat hippocampus neurons against cell death [23], which is in harmony with our results suggesting cytoprotective effects of NSO and especially MTSO. In fact, numerous studies indicate that molecules such as $\alpha$-tocopherol [40], polyphenols including quercetin [59,60], dimethyl fumarate [61], docosahexaenoic acid [40,44,62], and oleic acid [62] can prevent the toxicity of 7KC induced in oligodendrocytes, microglial, and neuronal cells. Similarly, some studies reported an attenuation of the cytotoxicity of $7 \beta-\mathrm{OHC}$ by docosahexaenoic acid, $\alpha$-tocopherol, and biotin [40,45]. We suggest that the bioactive molecules present in MTSO and NSO, such as thymoquinone, $\alpha$-tocopherol, quercetin, and/or oleic acid are responsible, at least in part, for the cytoprotection against $7 \beta-\mathrm{OHC}$-induced toxicity on SH-SY5Y cells.

\section{Conclusions}

Summarizing, $7 \beta-\mathrm{OHC}$ showed a complex of damages on SH-SY5Y cells, triggered by its anti-proliferative, pro-oxidative, and pro-apoptotic activities. Our study supports the contribution of oxysterols and especially, $7 \beta-\mathrm{OHC}$, in the development cellular dysfunctions associated with chronic diseases including neurodegenerative disorders. NSO and especially MTSO were able to protect cells against $7 \beta-\mathrm{OHC}$-induced toxicity. This study exhibits some limitations and opens several perspectives. In fact, the use of differentiated cells or primary culture would be considered a better model for neuronal cells, that mimic better physiological conditions. In addition, the use of purified bioactive molecules or 
mixtures of molecules to protect cells against oxysterols side effects would give them an advantage in considering therapeutic applications.

Supplementary Materials: The following are available online at https://www.mdpi.com/article/ 10.3390/biom11060797/s1, Figure S1: Vehicle controls for cell viability by MTT assays; Figure S2: NSO and MTSO concentration curves by MTT assays; Figure S3: Vehicle controls for cell viability by trypan blue test; Figure S4: Effect of NSO and MTSO associated with $\mathrm{H}_{2} \mathrm{O}_{2}$ on cell viability and proliferation by MTT assay (A) Effect of NSO $(50-150 \mu \mathrm{g} / \mathrm{mL})$ associated with $\mathrm{H}_{2} \mathrm{O}_{2}(100 \mu \mathrm{M})$ on cell viability and proliferation by MTT assay. (B) Effect of MTSO $(50-150 \mu \mathrm{g} / \mathrm{mL})$ associated with $\mathrm{H}_{2} \mathrm{O}_{2}(100 \mu \mathrm{M})$ on cell viability and proliferation by MTT assay. (C) Effect of trolox (50-150 $\mu \mathrm{g} / \mathrm{mL}$ ) associated with $\mathrm{H}_{2} \mathrm{O}_{2}(100 \mu \mathrm{M})$ on cell viability and proliferation by MTT assay.

Author Contributions: Conceptualization and writing-review and editing, A.Z.; methodology, P.P.P.; software, I.G.; resources, W.M.; data curation, W.K.; writing—original draft preparation, S.H. (Sonia Hammami); writing-review and editing, F.J.M.; supervision, M.H.; project administration, S.H. (Souha Hammouda). All authors have read and agreed to the published version of the manuscript.

Funding: This study was supported by the Ministry of Higher Education and Scientific Research (MHESR), Tunisia. This work was also supported by the Spanish Ministry of Science and Innovation and FEDER Funds through grants SAF2017-83372-R (FJM) and through the "María de Maeztu" Program for Units of Excellence in R\&D from Spain (award CEX2018-000792-M).

Institutional Review Board Statement: Not applicable.

Informed Consent Statement: Not applicable.

Data Availability Statement: Data supporting the findings of this study are available from the first author (Souha Hammouda) on request.

Acknowledgments: The authors are grateful to Khelifa Limem for donating some materials used for experiments). We wish to express our gratitude to Jean Paul Pais De Barros for performing some biochemical analyses and Gérard Lizard for providing the oxysterols.

Conflicts of Interest: The authors declare no conflict of interest.

\section{References}

1. Hannaoui, S.; Shim, S.; Cheng, Y.; Corda, E.; Gilch, S. Cholesterol Balance in Prion Diseases and Alzheimer's Disease. Viruses 2014, 6, 4505-4535. [CrossRef]

2. Testa, G.; Staurenghi, E.; Zerbinati, C.; Gargiulo, S.; Iuliano, L.; Giaccone, G.; Fantò, F.; Poli, G.; Leonarduzzi, G.; Gamba, P. Changes in Brain Oxysterols at Different Stages of Alzheimer's Disease: Their Involvement in Neuroinflammation. Redox Biol. 2016, 10, 24-33. [CrossRef] [PubMed]

3. Hammouda, S.; Ghzaiel, I.; Khamlaoui, W.; Hammami, S.; Mhenni, S.Y.; Samet, S.; Hammami, M.; Zarrouk, A. Genetic variants in FADS1 and ELOVL2 increase level of arachidonic acid and the risk of Alzheimer's disease in the Tunisian population. Prostaglandins Leukot. Essent. Fatty Acids 2020, 160, 102159. [CrossRef]

4. Zarrouk, A.; Hammouda, S.; Ghzaiel, I.; Hammami, S.; Khamlaoui, W.; Ahmed, S.H.; Lizard, G.; Hammami, M. Association between oxidative stress and altered cholesterol metabolism in Alzheimer's disease patients. Curr. Alzheimer Res. 2021, 17, 823-834. [CrossRef]

5. Poli, G.; Biasi, F; Leonarduzzi, G. Oxysterols in the pathogenesis of major chronic diseases. Redox Biol. 2013, 1, 125-130. [CrossRef] [PubMed]

6. Zarrouk, A.; Vejux, A.; Mackrill, J.; O'Callaghan, Y.; Hammami, M.; O'Brien, N.; Lizard, G. Involvement of oxysterols in age-related diseases and ageing processes. Ageing Res. Rev. 2014, 18, 148-162. [CrossRef] [PubMed]

7. Björkhem, I. Crossing the barrier: Oxysterols as cholesterol transporters and metabolic modulators in the brain. J. Intern. Med. 2006, 260, 493-508. [CrossRef]

8. Cheng, D.; Jenner, A.M.; Shui, G.; Cheong, W.F.; Mitchell, T.W.; Nealon, J.R.; Kim, W.S.; McCann, H.; Wenk, M.R.; Halliday, G.M.; et al. Lipid pathway alterations in Parkinson's disease primary visual cortex. PLoS ONE 2011, 6, e17299. [CrossRef]

9. Kreilaus, F.; Spiro, A.S.; McLean, C.A.; Garner, B.; Jenner, A.M. Evidence for altered cholesterol metabolism in Huntington's Disease Post Mortem brain tissue: Altered cholesterol metabolism in Huntington's Disease. Neuropathol. Appl. NeuroBiol. 2016, 42, 535-546. [CrossRef]

10. Nelson, T.J.; Alkon, D.L. Oxidation of cholesterol by amyloid precursor protein and $\beta$-amyloid peptide. J. Biol. Chem. 2005, 280, 7377-7387. [CrossRef] 
11. Nury, T.; Sghaier, R.; Zarrouk, A.; Ménétrier, F.; Uzun, T.; Leoni, V.; Caccia, C.; Meddeb, W.; Namsi, A.; Sassi, K.; et al. Induction of peroxisomal changes in oligodendrocytes treated with 7-ketocholesterol: Attenuation by $\alpha$-tocopherol. Biochimie 2018, 153, 181-202. [CrossRef]

12. Chiaravalloti, N.D.; DeLuca, J. Cognitive impairment in multiple sclerosis. Lancet Neurol. 2008, 7, 1139-1151. [CrossRef]

13. Ebers, G.C. Environmental factors and multiple sclerosis. Lancet Neurol. 2008, 7, 268-277. [CrossRef]

14. Balandrin, M.; Klocke, J.; Wurtele, E.; Bollinger, W. Natural Plant Chemicals: Sources of Industrial and Medicinal Materials. Science 1985, 228, 1154-1160. [CrossRef]

15. Traber, M.G.; Stevens, J.F. Vitamins C and E: Beneficial effects from a mechanistic perspective. Free Radic. Biol. Med. 2011, 51, 1000-1013. [CrossRef]

16. Cilla, A.; Alegría, A.; Attanzio, A.; Garcia-Llatas, G.; Tesoriere, L.; Livrea, M.A. Dietary phytochemicals in the protection against oxysterol-induced damage. Chem. Phys. Lipids 2017, 207, 192-205. [CrossRef]

17. Gholamnezhad, Z.; Havakhah, S.; Boskabady, M.H. Preclinical and clinical effects of nigella sativa and its constituent, thymoquinone: A review. J. Ethnopharmacol. 2016, 190, 372-386. [CrossRef]

18. Ikhsan, M.; Hiedayati, N.; Maeyama, K.; Nurwidya, F. Nigella Sativa as an anti-inflammatory agent in asthma. BMC Res. Notes 2018, 11, 744. [CrossRef] [PubMed]

19. Meddeb, W.; Rezig, L.; Zarrouk, A.; Nury, T.; Vejux, A.; Prost, M.; Bretillon, L.; Mejri, M.; Lizard, G. Cytoprotective activities of milk thistle seed oil used in traditional Tunisian medicine on 7-ketocholesterol and 24S-hydroxycholesterol-induced toxicity on 158N murine oligodendrocytes. Antioxidants 2018, 7, 95. [CrossRef] [PubMed]

20. Mohammed, N.K.; AbdManap, M.Y.; Tan, C.P.; Muhialdin, B.J.; Alhelli, A.M.; MeorHussin, A.S. The effects of different extraction methods on antioxidant properties, chemical composition, and thermal behavior of black seed (Nigella Sativa L.) oil. Evid. Based Complement. Alternat. Med. 2016, 2016, 1-10. [CrossRef] [PubMed]

21. Isik, S.; Kartal, M.; Erdem, S.A. Quantitative analysis of thymoquinone in Nigella sativa L. (black cumin) seeds and commercial seed oils and seed oil capsules from Turkey. Ankara Univ. Eczacilik Fak. Derg 2017, 41, 34-41. [CrossRef]

22. Parry, J.; Hao, Z.; Luther, M.; Su, L.; Zhou, K.; Yu, L.L. Characterization of cold-pressed onion, parsley, cardamom, mullein, roasted pumpkin, and milk thistle seed oils. J. Amer. Oil Chem. Soc. 2006, 83, 847-854. [CrossRef]

23. Kittur, S.; Wilasrusmee, S.; Pedersen, W.A.; Mattson, M.P.; Straube-West, K.; Wilasrusmee, C.; Jubelt, B.; Kittur, D.S. Neurotrophic and neuroprotective effects of milk thistle (Silybum Marianum) on neurons in culture. J. Mol. Neurosci. 2002, 18, 265-270. [CrossRef]

24. Moilanen, T.; Nikkari, T. The effect of storage on the fatty acid composition of human serum. Clin. Chim. Acta 1981, 114, 111-116. [CrossRef]

25. Zarrouk, A.; Martine, L.; Grégoire, S.; Nury, T.; Meddeb, W.; Camus, E.; Badreddine, A.; Durand, P.; Namsi, A.; Yammine, A.; et al. Profile of fatty acids, tocopherols, phytosterols and polyphenols in mediterranean oils (argan oils, olive oils, milk thistle seed oils and nigella seed oil) and evaluation of their antioxidant and cytoprotective activities. Curr. Pharm. Des. 2019, 25, 1791-1805. [CrossRef]

26. Lim, Y.Y.; Lim, T.T.; Tee, J.J. Antioxidant properties of several tropical fruits: A comparative study. Food Chem. 2007, 103, 1003-1008. [CrossRef]

27. Dinis, T.C.P.; Madeira, V.M.C.; Almeida, L.M. Action of phenolic derivatives (Acetaminophen, Salicylate, and 5-Aminosalicylate) as inhibitors of membrane lipid peroxidation and as peroxyl radical scavengers. Arch. Biochem. Biophys. 1994, 315, 161-169. [CrossRef]

28. Ragot, K.; Mackrill, J.J.; Zarrouk, A.; Nury, T.; Aires, V.; Jacquin, A.; Athias, A.; de Barros, J.-P.P.; Véjux, A.; Riedinger, J.-M.; et al. Absence of correlation between oxysterol accumulation in lipid raft microdomains, calcium increase, and apoptosis induction on 158N murine oligodendrocytes. Biochem. Pharmacol. 2013, 86, 67-79. [CrossRef]

29. Mosmann, T. Rapid colorimetric assay for cellular growth and survival: Application to proliferation and cytotoxicity assays. $J$. Immunol. Methods 1983, 65, 55-63. [CrossRef]

30. Egea, J.; Rosa, A.O.; Cuadrado, A.; García, A.G.; López, M.G. Nicotinic receptor activation by epibatidine induces heme oxygenase1 and protects chromaffin cells against oxidative stress: Epibatidine induces heme oxygenase-1 and protects against reactive oxygen species. J. Neurochem. 2007, 102, 1842-1852. [CrossRef]

31. Beauchamp, C.; Fridovich, I. Superoxide dismutase: Improved assays and an assay applicable to acrylamide gels. Anal. Biochem. 1971, 44, 276-287. [CrossRef]

32. Flohé, L.; Günzler, W.A. Assays of Glutathione Peroxidase. In Methods in Enzymology; Elsevier: Amsterdam, The Netherlands, 1984; Volume 105, pp. 114-120.

33. Faure, P.; Lafond, J.-L. Measurement of Plasma Sulfhydryl and Carbonyl Groups as a Possible Indicator of Protein Oxidation. In Analysis of Free Radicals in Biological Systems; Favier, A.E., Cadet, J., Kalyanaraman, B., Fontecave, M., Pierre, J.-L., Eds.; Birkhäuser Basel: Basel, Switzerland, 1995; pp. 237-248.

34. Bradford, M.M. A Rapid and sensitive method for the quantitation of microgram quantities of protein utilizing the principle of protein-dye binding. Anal. Biochem. 1976, 72, 248-254. [CrossRef]

35. Yoshioka, T.; Kawada, K.; Shimada, T.; Mori, M. Lipid peroxidation in maternal and cord blood and protective mechanism against activated-oxygen toxicity in the blood. Am. J. Obstet. Gynecol. 1979, 135, 372-376. [CrossRef]

36. Esterbauer, H.; Striegl, G.; Puhl, H.; Rotheneder, M. Continuous monitoring of in vitro oxidation of human low density lipoprotein. Free Radic. Res. Commun. 1989, 6, 67-75. [CrossRef] [PubMed] 
37. Sghaier, R.; Zarrouk, A.; Nury, T.; Badreddine, I.; O’Brien, N.; Mackrill, J.J.; Vejux, A.; Samadi, M.; Nasser, B.; Caccia, C.; et al. Biotin attenuation of oxidative stress, mitochondrial dysfunction, lipid metabolism alteration and 7 $\beta$-hydroxycholesterol-induced cell death in 158n murine oligodendrocytes. Free Radic. Res. 2019, 53, 535-561. [CrossRef]

38. Lemaire-Ewing, S.; Prunet, C.; Montange, T.; Vejux, A.; Berthier, A.; Bessède, G.; Corcos, L.; Gambert, P.; Néel, D.; Lizard, G. Comparison of the cytotoxic, pro-oxidant and pro-inflammatory characteristics of different oxysterols. Cell Biol. Toxicol. 2005, 21, 97-114. [CrossRef]

39. Lordan, S.; Mackrill, J.J.; O’Brien, N.M. Oxysterols and mechanisms of apoptotic signaling: Implications in the pathology of degenerative diseases. J. Nutr. Biochem. 2009, 20, 321-336. [CrossRef]

40. Nury, T.; Zarrouk, A.; Mackrill, J.J.; Samadi, M.; Durand, P.; Riedinger, J.-M.; Doria, M.; Vejux, A.; Limagne, E.; Delmas, D.; et al. Induction of oxiapoptophagy on $158 \mathrm{~N}$ murine oligodendrocytes treated by 7-ketocholesterol-, 7 $\beta$-hydroxycholesterol-, or 24(S)-hydroxycholesterol: Protective effects of $\alpha$-tocopherol and docosahexaenoic acid (DHA.; C22:6 n-3). Steroids 2015, 99, 194-203. [CrossRef]

41. Coma, M.; Guix, F.X.; Uribesalgo, I.; Espuña, G.; Solé, M.; Andreu, D.; Muñoz, F.J. Lack of oestrogen protection in amyloidmediated endothelial damage due to protein nitrotyrosination. Brain 2005, 128, 1613-1621. [CrossRef]

42. Mutemberezi, V.; Guillemot-Legris, O.; Muccioli, G.G. Oxysterols: From cholesterol metabolites to key mediators. Prog. Lipid Res. 2016, 64, 152-169. [CrossRef]

43. O'Brien, R.D. Fats and Oils: Formulating and Processing for Applications, 3rd ed.; CRC Press: Boca Raton, FL, USA, 2009.

44. Zarrouk, A.; Nury, T.; Samadi, M.; O'Callaghan, Y.; Hammami, M.; O’Brien, N.M.; Lizard, G.; Mackrill, J.J. Effects of cholesterol oxides on cell death induction and calcium increase in human neuronal cells (SK-N-BE) and evaluation of the protective effects of docosahexaenoic acid (DHA.; C22:6 n-3). Steroids 2015, 99, 238-247. [CrossRef]

45. Zarrouk, A.; Ben Salem, Y.; Hafsa, J.; Sghaier, R.; Charfeddine, B.; Limem, K.; Hammami, M.; Majdoub, H. 7 $\beta$-hydroxycholesterolinduced cell death, oxidative stress, and fatty acid metabolism dysfunctions attenuated with sea urchin egg oil. Biochimie 2018, 153, 210-219. [CrossRef] [PubMed]

46. Lemaire-Ewing, S.; Berthier, A.; Royer, M.C.; Logette, E.; Corcos, L.; Bouchot, A.; Monier, S.; Prunet, C.; Raveneau, M.; Rébé, C.; et al. 7 $\beta$-hydroxycholesterol and 25-hydroxycholesterol-induced interleukin-8 secretion involves a calcium-dependent activation of c-Fos via the ERK1/2 signaling pathway in THP-1 cells: Oxysterols-induced il-8 secretion is calcium-dependent. Cell Biol. Toxicol. 2009, 25, 127-139. [CrossRef] [PubMed]

47. Testa, G.; Gamba, P.; Badilli, U.; Gargiulo, S.; Maina, M.; Guina, T.; Calfapietra, S.; Biasi, F.; Cavalli, R.; Poli, G.; et al. Loading into nanoparticles improves quercetin's efficacy in preventing neuroinflammation induced by oxysterols. PLoS ONE 2014, 9, e96795 [CrossRef]

48. Kloudova, A.; Guengerich, F.P.; Soucek, P. The role of oxysterols in human cancer. Trends Endrocrinol. Metab. 2017, 28, 485-496. [CrossRef]

49. O'Callaghan, Y.C.; Woods, J.A.; O'Brien, N.M. Oxysterol-induced cell death in U937 and HepG2 cells at reduced and normal serum concentrations. Eur. J. Nutr. 1999, 38, 255-262. [CrossRef] [PubMed]

50. Lyons, N.M.; Woods, J.A.; O'Brien, N.M. $\alpha$-tocopherol, but not $\gamma$-tocopherol inhibits $7 \beta$-hydroxycholesterol-induced apoptosis in human U937 cells. Free Radic. Res. 2001, 35, 329-339. [CrossRef] [PubMed]

51. Roussi, S.; Winter, A.; Gosse, F.; Werner, D.; Zhang, X.; Marchioni, E.; Geoffroy, P.; Miesch, M.; Raul, F. Different apoptotic mechanisms are involved in the antiproliferative effects of $7 \beta$-hydroxysitosterol and $7 \beta$-hydroxycholesterol in human colon cancer cells. Cell Death Differ. 2005, 12, 128-135. [CrossRef]

52. Wielkoszyński, T.; Zalejska-Fiolka, J.; Strzelczyk, J.K.; Owczarek, A.J.; Cholewka, A.; Kokoszczyk, K.; Stanek, A. 5 $\alpha, 6 \alpha-$ epoxyphytosterols and $5 \alpha, 6 \alpha$-epoxycholesterol increase nitrosative stress and inflammatory cytokine production in rats on low-cholesterol diet. Oxid. Med. Cell. Longev. 2020, 2020, 1-9. [CrossRef]

53. El-Dakak, A.M.; Ahmed, M.H.; Ismail, S.A. Effect of some natural antioxidants on ox sterol formed endogenously in hypecholesterolemia rats. Egypt. J. Biomed. Sci. 2008, 28, 1-18.

54. Halliwell, B. What nitrates tyrosine? Is nitrotyrosine specific as a biomarker of peroxynitrite formation in vivo? FEBS Lett. 1997, 411, 157-160. [CrossRef]

55. Picón-Pagès, P.; Garcia-Buendia, J.; Muñoz, F.J. Functions and dysfunctions of nitric oxide in brain. Biochim. Biophys. Acta Mol. Basis Dis. 2019, 1865, 1949-1967. [CrossRef]

56. Cruz, D.F.; Fardilha, M. Relevance of peroxynitrite formation and 3-nitrotyrosine on spermatozoa physiology. Porto Biomed. J. 2016, 1, 129-135. [CrossRef]

57. Souza, J.M.; Peluffo, G.; Radi, R. Protein tyrosine nitration-Functional alteration or just a biomarker? Free Radic. Biol. Med. 2008, 45, 357-366. [CrossRef]

58. Bartesaghi, S.; Radi, R. Fundamentals on the biochemistry of peroxynitrite and protein tyrosine nitration. Redox Biol. 2018, 14, 618-625. [CrossRef]

59. Tesoriere, L.; Attanzio, A.; Allegra, M.; Gentile, C.; Livrea, M.A. Phytochemical Indicaxanthin suppresses 7-ketocholesterolinduced THP-1 cell apoptosis by preventing cytosolic $\mathrm{Ca}^{2+}$ increase and oxidative stress. Br. J. Nutr. 2013, 110, 230-240. [CrossRef] 
60. Guina, T.; Deiana, M.; Calfapietra, S.; Cabboi, B.; Maina, M.; Tuberoso, C.I.; Leonarduzzi, G.; Gamba, P.; Gargiulo, S.; Testa, G.; et al. The role of P38 MAPK in the induction of intestinal inflammation by dietary oxysterols: Modulation by wine phenolics. Food Funct. 2015, 6, 1218-1228. [CrossRef]

61. Zarrouk, A.; Nury, T.; Karym, E.-M.; Vejux, A.; Sghaier, R.; Gondcaille, C.; Andreoletti, P.; Trompier, D.; Savary, S.; CherkaouiMalki, M.; et al. Attenuation of 7-ketocholesterol-induced overproduction of reactive oxygen species, apoptosis, and autophagy by dimethyl fumarate on $158 \mathrm{~N}$ murine oligodendrocytes. J. Steroid Biochem. Mol. Biol. 2017, 169, 29-38. [CrossRef]

62. Debbabi, M.; Zarrouk, A.; Bezine, M.; Meddeb, W.; Nury, T.; Badreddine, A.; Karym, E.M.; Sghaier, R.; Bretillon, L.; Guyot, S.; et al. Comparison of the effects of major fatty acids present in the mediterranean diet (oleic acid, docosahexaenoic acid) and in hydrogenated oils (elaidic acid) on 7-ketocholesterol-induced oxiapoptophagy in microglial BV-2 cells. Chem. Phys. Lipids 2017, 207, 151-170. [CrossRef] [PubMed] 